\title{
Chromium (VI) Induced Biochemical Changes and Gum Content in Cluster Bean (Cyamopsis tetragonoloba L.) at Different Developmental Stages
}

\author{
Punesh Sangwan, ${ }^{1}$ Vinod Kumar, ${ }^{2}$ R. S. Khatri, ${ }^{3}$ and U. N. Joshi ${ }^{1}$ \\ ${ }^{1}$ Department of Biochemistry, CCS Haryana Agricultural University, Hisar 125001, India \\ ${ }^{2}$ Department of Biochemistry, G. B. Pant University of Agriculture and Technology, Pantnagar 263145, India \\ ${ }^{3}$ Department of Genetics and Plant Breeding, CCS Haryana Agricultural University, Hisar 125001, India \\ Correspondence should be addressed to Punesh Sangwan; puneshsangwan@gmail.com
}

Received 31 July 2013; Revised 4 November 2013; Accepted 17 November 2013

Academic Editor: Zed Rengel

Copyright (c) 2013 Punesh Sangwan et al. This is an open access article distributed under the Creative Commons Attribution License, which permits unrestricted use, distribution, and reproduction in any medium, provided the original work is properly cited.

Chromium (Cr) contamination by various industries and other activities is known to inhibit plants growth and development. The present study was conducted using pot experiments in a net house to determine the effect of $\mathrm{Cr}$ (VI) on biochemical parameters such as photosynthetic pigments, reducing sugars, and important minerals at different stages of growth in leaves, stem, and roots of clusterbean, a multipurpose fodder crop including a source of guar gum. Guar gum content was estimated in seeds at maturity. All biochemical contents showed a great variation with respect to increase in $\mathrm{Cr}$ concentration at different stages of growth. The levels of $\mathrm{K}, \mathrm{Fe}$, and $\mathrm{Zn}$ decreased, while $\mathrm{Cr}$ and $\mathrm{Na}$ content increased with increase in $\mathrm{Cr}$ concentration. $\mathrm{Cr}$ induced toxicity in clusterbean appears at $0.5 \mathrm{mg} \mathrm{Cr}(\mathrm{VI}) \mathrm{Kg}^{-1}$ soil with maximum inhibitory effect at $2 \mathrm{mg} \mathrm{Cr}(\mathrm{VI}) \mathrm{Kg}^{-1}$ soil, where impaired sugar supply resulted in decreased guar gum synthesis and altered micronutrient content. The study reveals the possible role of these biochemical parameters in decreasing plant growth and development under heavy metal stress.

\section{Introduction}

The molecular and physiological basis of crop plant interactions with the environment has attracted considerable interest in recent years. Being sessile organisms, plants are constantly exposed during their life cycle to adverse environmental conditions that negatively affect growth, development, or productivity. The presence of toxic heavy metals from various industrial activities causes damage to plants by altering major plant physiological and metabolic processes $[1,2]$. These metals enter into the soil through different ways including use of fertilizers and pesticides [3].

Crop plants growing in high levels of chromium (Cr) showed a series of physiological disorders, such as reduction of chlorophyll content, sugars, and protein content and decreased photosynthesis leading to lower yield and plant death $[4,5]$. Among variable forms of $\mathrm{Cr}$, highly reactive $\mathrm{Cr}$ (VI) was found to be toxic to plants in high concentration remaining stable for several months in the soil without changing its oxidation state [6]. It was mainly released in the soil from leather tanning, textile, carpet, electroplating industries, mining industry, and metal cleaning $[7,8]$. The interactions between $\mathrm{Cr}$ and other nutrients led to changes in nutrient content and physiological disorders with reduction of plant growth and yield. The uptake of several nutrients (potassium $(\mathrm{K})$, magnesium $(\mathrm{Mg})$, phosphorus $(\mathrm{P})$, manganese $(\mathrm{Mn})$, and iron $(\mathrm{Fe})$ ) by plants is hindered by high $\mathrm{Cr}$ levels [9]. $\mathrm{Cr}$ is carcinogenic to humans and also causes cirrhosis and DNA damage [10]. Due to this toxicity to plants, human health, and environment, Cr toxicity has become an increasing target of studies.

Among the different models available to study metal toxicity, plants present some unique features that make them interesting subjects. Much of human diet depends directly on plant products like fruits and vegetables or indirectly as fodder given to livestock. Accumulation of heavy metals in 
the edible parts of plants represents a direct pathway for their incorporation into the human food chain [11]. ClusterBean (Cyamopsis tetragonoloba L. "Taub”), a drought-hardy grain legume which belongs to the family Leguminosae, is an important kharif crop known as "Guar" is cultivated throughout India for its edible pod and as fodder crop. It also one of the most important commercial sources for seed gum "guar gum," which contains up to $75-85 \%$ of galactomannan. It is the most cost-effective natural thickener and has several other industrial applications [12].

In India, $\mathrm{Cr}(\mathrm{VI})$ contamination is a major problem around various industries using $\mathrm{Cr}$ compounds, which causes considerable negative impact on crop production [13]. In Haryana (a major guar producing state), Sonepat, Panipat, Dharuhera, Gurgaon, Yamunanagar, Faridabad, and Shahabad are the main industrial areas, where poor plant growth of field crops has been observed [14]. Hence, the present investigation was designed and conducted to investigate the impact of $\mathrm{Cr}$ on biochemical composition and minerals content and uptake by Cluster-Bean from soil.

\section{Material and Methods}

2.1. Chemicals, Reagents, and Experimental Soil. The chemicals and reagents used during the present investigation were of analytical grade. A nutrient deficient loamy sand soil was used in the present study. The characteristics of soil were as follows: $\mathrm{pH}(1: 2), 8.50$; organic carbon, $0.22 \%$; $4.0 \mathrm{mg} \mathrm{kg}^{-1}$ soil; $\mathrm{P}, 13.0 \mathrm{mg} \mathrm{kg}^{-1}$ soil; $\mathrm{K}, 163 \mathrm{mg} \mathrm{kg}^{-1}$ soil; $\mathrm{Zn}^{2+}$, $0.61 \mathrm{mg} \mathrm{kg}^{-1}$ soil; $\mathrm{Fe}^{2+}, 0.9 \mathrm{mg} \mathrm{kg}^{-1}$ soil; $\mathrm{Cu}^{2+}, 0.18 \mathrm{mg} \mathrm{kg}^{-1}$ soil; $\mathrm{Mn}^{2+}, 3.6 \mathrm{mg} \mathrm{kg}^{-1}$ soil; $\mathrm{EC}, 1.5 ; \mathrm{CaCO}_{3}, 3.5 \%$; $\mathrm{Cr}^{2+}$, $0.01 \mathrm{mg} \mathrm{kg}^{-1}$ soil; texture-sandy loam.

2.2. Plant Growth Conditions and Exposure to Chromium. Seeds of Cluster-Bean cv. HG 2-20 were procured from Forage Section, Department of Genetics and Plant Breeding, CCS Haryana Agricultural University, Hisar. The seeds were surface-sterilized with mercuric chloride and, after proper washing with distilled water, inoculated with Rhizobium culture. Crop (cv. HG 2-20) was raised in pots filled with $5 \mathrm{~kg}$ of sandy loam soil in a naturally lit net house of the Department of Biochemistry, CCS Haryana Agricultural University, Hisar. The pots were lined with polythene bags and the soil in each pot was treated with different levels of $\mathrm{Cr}$ in the form of potassium dichromate, that is, $0.0,0.5,1.0$, 2.0 , and $4.0 \mathrm{mg} \mathrm{kg}^{-1}$ soil. Equal amount of nutrient solution was supplied at a weekly interval to each pot. The plants were irrigated with equal quantities of tap water as and when required. The ambient temperature was 11.0 to $35.6^{\circ} \mathrm{C}$ and humidity was 34.5 to $95.2 \%$.

\subsection{Determination of Chlorophylls, Sugars, and Minerals.} Photosynthetic pigments, reducing sugar, and mineral contents were measured in different plant parts from each treatment at vegetative (30 days after sowing, i.e., $30 \mathrm{DAS}$ ), flowering (50 DAS), and grain filling stages (65 DAS). The photosynthetic pigments, that is, total chlorophyll, chlorophyll "a," chlorophyll "b," and carotenoids, in the first fully expanded leaf were extracted and estimated as per the method of Hiscox and Israelstam [15]. Washed and finely chopped leaves (excluding veins) weighing $100 \mathrm{mg}$ were placed in a tube containing $5 \mathrm{~mL}$ DMSO. The chlorophyll was extracted into the DMSO without grinding by incubating at $65^{\circ} \mathrm{C}$ for $1 \mathrm{~h}$. The extracted liquid was transferred to a $10 \mathrm{~mL}$ graduated cylinder and volume was made up to the mark with DMSO. The absorbance of the colour was measured at $450 \mathrm{~nm}$ for carotenoids and at $645 \mathrm{~nm}$ and $663 \mathrm{~nm}$ for total chlorophyll and chlorophyll "a" and chlorophyll "b" using DMSO as blank.

For sampling of plant material for reducing sugar and minerals, leaves, stem, and roots were separated, and after washing, air dried and then dried in a hot air oven maintained at $70^{\circ} \mathrm{C}$, grounded in a Wiley macromill and stored in paper bags with proper labelling. For extraction of sugars, $100 \mathrm{mg}$ of powdered samples was taken in a $100 \mathrm{~mL}$ flat bottom volumetric flask with $10 \mathrm{~mL}$ of $80 \%$ ethanol. The flask was kept in a water bath, maintained at $70^{\circ} \mathrm{C}$ for $1 \mathrm{~h}$, and the filtrate was collected in a $25 \mathrm{~mL}$ volumetric flask. The extraction procedure was repeated five times. The final volume was made to $25 \mathrm{~mL}$ with $80 \%$ ethanol. Reducing sugars were determined following the method of Nelson [16].

For determination of $\mathrm{Fe}, \mathrm{Zn}$, and $\mathrm{Cr}$ content, the dried samples were digested in $4: 1 \mathrm{HNO}_{3}: \mathrm{HClO}_{4}(\mathrm{v} / \mathrm{v})$ and these elements were estimated by an atomic absorption spectrophotometer (PERKIN-ELMER 2380). K and Na were estimated by the digital flame photometer (Model CL-22D) after calibrating with standard potassium and sodium solutions [17].

2.4. Guar Gum Analysis. Gum content in seeds was estimated by the method of Das et al. [18] and modified by Joshi [19]. Seed samples were ground by using a Cyclotec grinding mill (with $0.5 \mathrm{~mm}$ sieve). $100 \mathrm{mg}$ ground sample was weighed and transferred to a conical flask with $40 \mathrm{~mL}$ of $0.01 \mathrm{M} \mathrm{HgCl}_{2}$ and autoclaved at $15 \mathrm{psi}$ for $1 \mathrm{~h}$. The samples were cooled and volume was made to $100 \mathrm{~mL}$ with distilled water. $10 \mathrm{~mL}$ from this extract was taken and centrifuged at $5000 \mathrm{rpm}$ for $15 \mathrm{~min}$, $0.5 \mathrm{~mL}$ of supernatant was taken in another centrifuge tube, and $4.5 \mathrm{~mL}$ ethyl alcohol was added to make $90 \%$ alcohol. The solution was kept overnight and centrifuged at $5000 \mathrm{rpm}$ to remove supernatant. The residue was dissolved in $0.01 \mathrm{M}$ $\mathrm{HgCl}_{2}(5 \mathrm{~mL})$ by boiling in the water bath for $1 \mathrm{~h}$. After cooling, volume was made to $5 \mathrm{~mL} .1 \mathrm{~mL}$ of the extract was taken in a test tube and $2 \mathrm{~mL}$ of $2 \%$ phenol was added. Finally, $5 \mathrm{~mL}$ concentrated $\mathrm{H}_{2} \mathrm{SO}_{4}$ was added followed by shaking and cooling for $30 \mathrm{~min}$. Standard and blank were run simultaneously and absorbance was measured at $490 \mathrm{~nm}$. Standard curve was prepared using galactose: mannose in $1: 2$ ratio.

2.5. Statistical Analysis. All estimations were made in triplicate and given values are mean of three replicates. A twofactorial ANOVA in complete randomized block design was used to confirm the validity of the data using OPSTAT software available on CCSHAU website home page (http:// hau.ernet.in/opstat.html). In each table, standard errors (SE) 
TABLE 1: Effect of Cr (VI) on total chlorophyll, chlorophyll a and b, and carotenoids ( $\mathrm{mg} \mathrm{g}^{-1}$ fresh weight) in leaves of clusterbean plant at different stages of growth.

\begin{tabular}{|c|c|c|c|c|c|c|c|c|c|c|c|c|}
\hline \multirow{3}{*}{$\begin{array}{l}\mathrm{Cr}(\mathrm{VI}) \\
\mathrm{mg} \mathrm{kg}^{-1} \text { soil }\end{array}$} & \multicolumn{12}{|c|}{ Days after sowing (DAS) } \\
\hline & 30 & 50 & 65 & 30 & 50 & 65 & 30 & 50 & 65 & 30 & 50 & 65 \\
\hline & \multicolumn{3}{|c|}{ Total chlorophyll } & \multicolumn{3}{|c|}{ Chlorophyll a } & \multicolumn{3}{|c|}{ Chlorophyll b } & \multicolumn{3}{|c|}{ Carotenoids } \\
\hline 0.0 & 2.73 & 3.32 & 2.69 & 1.64 & 1.81 & 1.56 & 0.27 & 0.39 & 0.28 & 0.81 & 1.11 & 0.84 \\
\hline 0.5 & 2.61 & 2.84 & 2.38 & 1.48 & 1.56 & 1.37 & 0.22 & 0.31 & 0.25 & 0.89 & 0.96 & 0.75 \\
\hline 1.0 & 2.03 & 2.33 & 1.94 & 1.22 & 1.33 & 1.11 & 0.16 & 0.26 & 0.20 & 0.66 & 0.74 & 0.61 \\
\hline \multirow[t]{2}{*}{2.0} & 1.75 & 1.87 & 1.58 & 0.98 & 1.06 & 0.88 & 0.10 & 0.19 & 0.14 & 0.55 & 0.65 & 0.50 \\
\hline & A & B & $\mathrm{A} \times \mathrm{B}$ & A & B & $\mathrm{A} \times \mathrm{B}$ & A & B & $\mathrm{A} \times \mathrm{B}$ & A & B & $\mathrm{A} \times \mathrm{B}$ \\
\hline $\mathrm{SE}(\mathrm{m})$ & 0.01 & 0.01 & 0.01 & 0.02 & 0.01 & 0.01 & 0.01 & 0.01 & 0.02 & 0.02 & 0.01 & 0.01 \\
\hline $\mathrm{CD}$ at $5 \%$ & 0.02 & 0.03 & 0.02 & 0.04 & 0.02 & 0.02 & 0.03 & 0.03 & 0.05 & 0.07 & 0.02 & 0.03 \\
\hline
\end{tabular}

of mean and critical difference $(\mathrm{CD})$ at $5 \%$ values for treatment $(\mathrm{A})$, stages $(\mathrm{B})$, and interaction between treatments and stages $(\mathrm{A} \times \mathrm{B})$ are given.

\section{Result and Discussion}

Inspection of visible toxicity symptoms of Cr (VI) on ClusterBean revealed no visible symptoms on Cluster-Bean leaves grown in pots treated with $0.5 \mathrm{mg} \mathrm{Cr}$ (VI) kg-1 soil. However, plants grown in higher concentration of $\mathrm{Cr}$ (VI) amended soils revealed poor and stunted growth as compared to that of control. At higher concentration, namely, 1, 2, and $4 \mathrm{mg} \mathrm{Cr}$ (VI) $\mathrm{kg}^{-1}$ soil, the symptoms of toxicity in terms of poor and stunted growth started to appear after seven days of sowing. The plants did not survive after 20 DAS at $4.0 \mathrm{mg} \mathrm{Cr}$ (VI) $\mathrm{kg}^{-1}$ soil. Therefore, proposed biochemical analysis at different growth stages was done in plant samples grown up to $2 \mathrm{mg}$ Cr (VI) $\mathrm{kg}^{-1}$ soil.

3.1. Biochemical Parameters. Chlorophyll "a" and " $b$ " and "total chlorophyll" content in leaves of Cluster-Bean plants decreased with increase in chromium concentration from 0.0 to $2.0 \mathrm{mg} \mathrm{Cr}$ (VI) $\mathrm{kg}^{-1}$ soil. Maximum reduction was observed at $2.0 \mathrm{mg} \mathrm{Cr}$ (VI) $\mathrm{kg}^{-1}$ soil. Similarly, carotenoids contents ( $\mathrm{mgg}^{-1}$ fresh weight) also decreased in leaves of Cluster-Bean plants treated with $\mathrm{Cr}$ (VI). The decreasing trend was observed at all the stages of growth, that is, 30, 50, and 65 DAS (Table 1). Total chlorophyll content decreased by $35.9,43.7$, and $41.3 \%$, chlorophyll "a" decreased by $40.2,41.4$ and $43.6 \%$, chlorophyll "b" decreased by $63.0,51.3$, and $50.0 \%$, and carotenoids content decreased by $32.1,41.4$, and $40.5 \%$ in leaves of $2.0 \mathrm{mg} \mathrm{Cr}(\mathrm{VI}) \mathrm{kg}^{-1}$ soil treated plants over the control at 30,50, and 65 DAS, respectively. The concentration of total chlorophyll, chlorophyll "a," and chlorophyll "b" reached maximum level at $50 \mathrm{DAS}$ and then declined at later stages of plant growth. A similar concentration dependent reduction in chlorophyll content over control was also observed in the leaves of Lycopersicon esculentum [20], Eichhornia crassipes [21], and Brassica juncea $[22,23]$. This was attributed to the Cr toxicity degradation of aminolevulinic acid dehydratase, which reduces the availability of prophobilinogen required for chlorophyll biosynthesis, thereby affecting the amino levulinic acid (ALA) utilization. This causes ALA buildup and finally reduces the chlorophyll level [24]. Besides these effects, Cr can alter chloroplast and membrane ultrastructure in plants [25]. It can also cause ultrastructural changes in chloroplast leading to inhibition of photosynthesis [23]. $\mathrm{Cr}$ also reduced carotenoid content in Cluster-Bean which served as accessory pigments for photosynthesis and also protect the plants from photooxidation. Similar results were also observed in O. tenuiflorum, lettuce, and soybean [26, 27]. The amount of carotenoids dropped continuously after attaining maximum value at 50 DAS (Table 1).

Sugars are considered as important metabolites in plant metabolism not only because these are the first complex organic compounds formed in the plant as a result of photosynthesis but also because they provide a major source of respiratory energy [28]. During, present study, altered level of reducing sugars was observed in $\mathrm{Cr}$ treated plants. Reducing sugars registered an increasing trend in all plant parts in response to $\mathrm{Cr}$ (VI) exposure to Cluster-Bean plant (Table 2). Compared to control, reducing sugars content after exposure to $2.0 \mathrm{mg} \mathrm{Cr}$ (VI) $\mathrm{kg}^{-1}$ soil increased by $227 \%$ in leaves, whereas in stem and roots it increased by 175.9 and $190.6 \%$ at 50 DAS, respectively. The amount of reducing sugars increased with increasing age of plants up to 50 DAS thereafter decreased at 65 DAS and in each treatment (Table 2). Tiwari et al. [29] also observed increase in the amount of reducing sugar in pea plants with exposure to increasing $\mathrm{Cr}$ concentrations. Altered sugars content may be due to $\mathrm{Cr}$ induced alternation of carbohydrate metabolism as a result of its possible interaction with the reactive centre of ribulose bisphosphate carboxylase [29, 30]. Najafian et al. [31] observed that increased $\mathrm{Cr}$ caused a change in structure of cell membrane and inhibited growth of plant. Therefore, increase in reducing sugar showed the adaptation of plant to maintain osmotic condition and defence of biomolecules and membranes. Moreover, the plant can maintain osmotic potential and carbohydrate supplement in this situation [32].

In the present study, yellowing and burning of leaves were observed as a sign of nutrient depletion. The content of nutritionally important minerals, like $\mathrm{Na}, \mathrm{K}, \mathrm{Fe}$, and $\mathrm{Zn}$, was also determined in different plant parts of Cluster-Bean under $\mathrm{Cr}$ stress at these three developmental stages. Cr content ( $\mu \mathrm{gg}^{-1}$ dry weight) in plant tissues (leaves, stem, and root) 
TABLE 2: Effect of Cr (VI) on reducing sugars (\% dry weight) in clusterbean plant parts at different stages of growth.

\begin{tabular}{|c|c|c|c|c|c|c|c|c|c|}
\hline \multirow{3}{*}{$\begin{array}{l}\mathrm{Cr}(\mathrm{VI}) \\
\mathrm{mg} \mathrm{kg}^{-1} \text { soil }\end{array}$} & \multicolumn{9}{|c|}{ Days after sowing (DAS) } \\
\hline & 30 & 50 & 65 & 30 & 50 & 65 & 30 & 50 & 65 \\
\hline & \multicolumn{3}{|c|}{ Leaves } & \multicolumn{3}{|c|}{ Stem } & \multicolumn{3}{|c|}{ Root } \\
\hline 0.0 & 0.84 & 1.29 & 0.93 & 0.86 & 1.74 & 1.29 & 0.24 & 0.64 & 0.51 \\
\hline 0.5 & 0.93 & 2.56 & 1.25 & 1.27 & 2.58 & 2.16 & 0.42 & 0.84 & 0.73 \\
\hline 1.0 & 1.44 & 3.41 & 2.19 & 1.90 & 3.92 & 3.24 & 0.56 & 1.05 & 0.85 \\
\hline \multirow[t]{2}{*}{2.0} & 2.15 & 4.22 & 3.18 & 2.88 & 4.80 & 4.00 & 0.73 & 1.86 & 1.10 \\
\hline & A & $\mathrm{B}$ & $\mathrm{A} \times \mathrm{B}$ & $\mathrm{A}$ & $\mathrm{B}$ & $\mathrm{A} \times \mathrm{B}$ & $\mathrm{A}$ & $\mathrm{B}$ & $\mathrm{A} \times \mathrm{B}$ \\
\hline $\mathrm{SE}(\mathrm{m})$ & 0.02 & 0.026 & 0.04 & 0.03 & 0.03 & 0.06 & 0.02 & 0.04 & 0.05 \\
\hline $\mathrm{CD}$ at $5 \%$ & 0.06 & 0.07 & 0.13 & 0.10 & 0.11 & 0.19 & 0.07 & 0.13 & 0.16 \\
\hline
\end{tabular}

TABLE 3: Effect of Cr (VI) on chromium content ( $\mu \mathrm{g} \mathrm{g}^{-1}$ dry weight) in clusterbean plant parts at different stages of growth.

\begin{tabular}{|c|c|c|c|c|c|c|c|c|c|}
\hline \multirow{3}{*}{$\begin{array}{l}\mathrm{Cr}(\mathrm{VI}) \\
\mathrm{mg} \mathrm{kg}^{-1} \text { soil }\end{array}$} & \multicolumn{9}{|c|}{ Days after sowing (DAS) } \\
\hline & 30 & 50 & 65 & 30 & 50 & 65 & 30 & 50 & 65 \\
\hline & \multicolumn{3}{|c|}{ Leaves } & \multicolumn{3}{|c|}{ Stem } & \multicolumn{3}{|c|}{ Root } \\
\hline 0.0 & 0 & 0 & 0 & 0 & 0 & 0 & 0 & 0 & 0 \\
\hline 0.5 & 0.41 & 1.15 & 2.23 & 0.65 & 1.34 & 2.12 & 1.83 & 3.97 & 5.32 \\
\hline 1.0 & 0.80 & 1.575 & 2.65 & 1.13 & 1.94 & 2.65 & 4.21 & 6.06 & 7.23 \\
\hline \multirow[t]{2}{*}{2.0} & 1.16 & 2.41 & 3.27 & 2.72 & 3.26 & 3.82 & 7.76 & 8.47 & 10.64 \\
\hline & A & B & $\mathrm{A} \times \mathrm{B}$ & A & B & $\mathrm{A} \times \mathrm{B}$ & A & B & $\mathrm{A} \times \mathrm{B}$ \\
\hline $\mathrm{SE}(\mathrm{m})$ & 0.01 & 0.02 & 0.01 & 0.02 & 0.03 & 0.04 & 0.01 & 0.03 & 0.04 \\
\hline $\mathrm{CD}$ at $5 \%$ & 0.02 & 0.05 & 0.03 & 0.07 & 0.08 & 0.11 & 0.04 & 0.11 & 0.13 \\
\hline
\end{tabular}

significantly increased with increasing concentration of $\mathrm{Cr}$ treatment from 0.0 to $2.0 \mathrm{mg} \mathrm{Cr}$ (VI) kg-1 soil. At $50 \mathrm{DAS}$, $\mathrm{Cr}$ content increased from 0 to 2.41 in leaves, 0 to 3.26 in stem, and 0 to 8.47 in root of plants grown in soil containing 0.0 to $2.0 \mathrm{mg} \mathrm{Cr}$ (VI) $\mathrm{kg}^{-1}$ soil, respectively. Increase in $\mathrm{Cr}$ content was more in roots followed by stem and leaves. With advancement of age, $\mathrm{Cr}$ content also increased in leaves, stem and roots of $\mathrm{Cr}$ (VI) treated plants with maximum value at 65 DAS (Table 3 ). The highest chromium content was observed in roots followed by that is stem and leaves in all treatments. Such a high metal concentration in the root tissues may be due to immobilization of metal by cell wall and extracellular carbohydrates, which may be an important defence strategy adopted by plants. This might also be attributed to $\mathrm{Cr}$ compartmentalization in the root vacuoles, as a defence mechanism against its toxicity and a potential tolerance mechanism operating in plants under metal stress, or its retention in the cation exchange sites of the vessel walls of xylem parenchyma cells in roots [4, 24, 33, 34]. Probable reduction of $\mathrm{Cr}$ (VI) to $\mathrm{Cr}$ (III), which reduces its mobility from roots to stem, might also be a reason of comparatively lower accumulation of $\mathrm{Cr}$ in leaves than the roots [26]. With increase in the age of the plant, however, the ability to transfer the metal to aerial parts increased, leading to a higher $\mathrm{Cr}$ accumulation in the aboveground plant parts, especially in the stem [24].

Results presented in Table 4 revealed that increasing concentration of $\mathrm{Cr}(\mathrm{VI})$ registered an increase in Na content in leaves, stem, and root of Cluster-Bean. At 50 DAS, it increased by $69.21,83.73$, and $55.3 \%$ with $2.0 \mathrm{mg} \mathrm{Cr}$ (VI) $\mathrm{kg}^{-1}$ soil over the control in leaves, stem, and root, respectively. The increase in $\mathrm{Na}$ content was much more pronounced at $2.0 \mathrm{mg}$ $\mathrm{Cr}$ (VI) $\mathrm{kg}^{-1}$ soil. The advancement in growth resulted in an increase in $\mathrm{Na}$ content in these parts and maximum content was observed at 50 DAS (Table 4).

Data shown in Table 5 indicates that Cr (VI) addition to soil leads to decreased $\mathrm{K}$ content in leaves, stem, and root as compared to that in the control plants, where no $\mathrm{Cr}$ (VI) was added to soil. Increasing concentrations of $\mathrm{Cr}$ also caused marked decrease in K contents in Brassica [22]. As compared to the control, the decline in K content at 50 DAS was $24.8 \%$ in leaves, $19.13 \%$ in stem, and $35.7 \%$ in root, with $2.0 \mathrm{mg} \mathrm{Cr}$ (VI) $\mathrm{kg}^{-1}$ soil, respectively. Maximum decrease in $\mathrm{K}$ content at $2.0 \mathrm{mg} \mathrm{Cr} \mathrm{VI}) \mathrm{kg}^{-1}$ soil was recorded in leaves followed by that in stem and root. With the advancement of plant age, the $\mathrm{K}$ content increased up to 50 DAS and then decreased at 65 DAS.

$\mathrm{Fe}$ is required for the functioning of a range of enzymes, especially those involved in oxidation and reduction processes, for synthesis of the porphyrin ring (chlorophyll and heme biosynthesis), reduction of nitrite and sulphate, and $\mathrm{N}_{2}$-fixation (as part of leghemoglobin) [35]. Fe content in leaves decreased with progressive increase in $\mathrm{Cr}$ (VI) concentration, that is, from 0.0 to $2.0 \mathrm{mg} \mathrm{Cr}$ (VI) kg $\mathrm{kg}^{-1}$ soil. The visible toxic symptoms of $\mathrm{Cr}$ (VI) were superficially somewhat similar to those of Fe deficiency and are in support of the aforementioned data. The concentration of $\mathrm{Fe}$ was higher in root of Cluster-Bean plant than in leaves and stem (Table 6). The Fe content of leaves, stem, and root increased gradually up to 50 DAS and then decreased till 
TABLE 4: Effect of Cr (VI) on sodium content $\left(\mu \mathrm{gg}^{-1}\right.$ dry weight) in clusterbean plant parts at different stages of growth.

\begin{tabular}{|c|c|c|c|c|c|c|c|c|c|}
\hline \multirow{3}{*}{$\begin{array}{l}\mathrm{Cr}(\mathrm{VI}) \\
\mathrm{mg} \mathrm{kg}^{-1} \text { soil }\end{array}$} & \multicolumn{9}{|c|}{ Days after sowing (DAS) } \\
\hline & 30 & 50 & 65 & 30 & 50 & 65 & 30 & 50 & 65 \\
\hline & \multicolumn{3}{|c|}{ Leaves } & \multicolumn{3}{|c|}{ Stem } & \multicolumn{3}{|c|}{ Root } \\
\hline 0.0 & 1.27 & 5.62 & 4.94 & 1.12 & 6.58 & 5.20 & 0.63 & 3.42 & 3.11 \\
\hline 0.5 & 2.39 & 6.73 & 5.22 & 1.76 & 8.41 & 7.11 & 0.95 & 4.14 & 3.91 \\
\hline 1.0 & 2.76 & 7.26 & 6.38 & 2.58 & 9.89 & 8.83 & 1.26 & 4.73 & 4.17 \\
\hline \multirow[t]{2}{*}{2.0} & 4.15 & 9.51 & 7.17 & 3.39 & 12.09 & 11.24 & 2.07 & 5.31 & 4.65 \\
\hline & A & B & $A \times B$ & A & B & $A \times B$ & A & B & $A \times B$ \\
\hline $\mathrm{SE}(\mathrm{m})$ & 0.01 & 0.02 & 0.01 & 0.01 & 0.02 & 0.01 & 0.05 & 0.05 & 0.09 \\
\hline $\mathrm{CD}$ at $5 \%$ & 0.03 & 0.04 & 0.04 & 0.03 & 0.05 & 0.04 & 0.13 & 0.15 & 0.27 \\
\hline
\end{tabular}

TABLE 5: Effect of Cr (VI) on potassium content ( $\mu \mathrm{g} \mathrm{g}^{-1}$ dry weight) in clusterbean plant parts at different stages of growth.

\begin{tabular}{|c|c|c|c|c|c|c|c|c|c|}
\hline \multirow{3}{*}{$\begin{array}{l}\mathrm{Cr}(\mathrm{VI}) \\
\mathrm{mg} \mathrm{Kg}^{-1} \text { soil }\end{array}$} & \multicolumn{9}{|c|}{ Days after sowing (DAS) } \\
\hline & 30 & 50 & 65 & 30 & 50 & 65 & 30 & 50 & 65 \\
\hline & \multicolumn{3}{|c|}{ Leaves } & \multicolumn{3}{|c|}{ Stem } & \multicolumn{3}{|c|}{ Root } \\
\hline 0.0 & 15.32 & 43.43 & 42.93 & 16.33 & 56.28 & 51.61 & 11.34 & 24.61 & 21.14 \\
\hline 0.5 & 13.15 & 38.58 & 35.48 & 15.27 & 54.73 & 47.96 & 9.33 & 21.67 & 19.94 \\
\hline 1.0 & 9.06 & 36.22 & 33.29 & 16.24 & 47.56 & 45.79 & 6.725 & 18.63 & 17.13 \\
\hline \multirow[t]{2}{*}{2.0} & 7.59 & 32.66 & 28.88 & 13.88 & 45.51 & 43.38 & 4.79 & 15.83 & 13.96 \\
\hline & A & B & $\mathrm{A} \times \mathrm{B}$ & A & B & $A \times B$ & A & B & $\mathrm{A} \times \mathrm{B}$ \\
\hline $\mathrm{SE}(\mathrm{m})$ & 0.04 & 0.04 & 0.08 & 0.06 & 0.06 & 0.12 & 0.06 & 0.07 & 0.01 \\
\hline $\mathrm{CD}$ at $5 \%$ & 0.11 & 0.13 & 0.23 & 0.17 & 0.20 & 0.35 & 0.17 & 0.20 & 0.03 \\
\hline
\end{tabular}

the last sampling (i.e., 65 DAS). It decreased by $79.0 \%$ in leaves, $78 \%$ in stem, and $64.1 \%$ in root over the control at 50 DAS with $2.0 \mathrm{mg} \mathrm{Cr}(\mathrm{VI}) \mathrm{kg}^{-1}$ soil, respectively. These toxic effects of $\mathrm{Cr}$ are suggested because of restricted Fe uptake and accumulation in Cluster-Bean plants associated with $\mathrm{Cr}$ contaminated site, which is related in part to the ability of $\mathrm{Cr}$ to displace other metals (particularly $\mathrm{Fe}$ ) from physiologically important centres, producing Fe deficiency [36]. Lower Fe concentration might also be due to competition between $\mathrm{Cr}$ and $\mathrm{Fe}$ for transport binding or higher Fe efflux from the plants. Cr might influence uptake of Fe by inhibiting $\mathrm{Fe}$ reductase activity and inhibit photosynthesis [37, 38].

$\mathrm{Zn}$ content in leaves also revealed a decreasing trend with increase in chromium concentration from 0.0 to $2.0 \mathrm{mg} \mathrm{Cr}$ (VI) $\mathrm{kg}^{-1}$ soil. It might be possibly due to excess $\mathrm{Cr}$ affected translocation of $\mathrm{Zn}$ in leaves, stem, and root of the ClusterBean plants or role of $\mathrm{Zn}$ in oxidative stress control [39]. Maximum decrease in $\mathrm{Zn}$ content was observed in plants treated with $2.0 \mathrm{mg} \mathrm{Cr}(\mathrm{VI}) \mathrm{kg}^{-1}$ soil at all stages of growth (Table 7). Compared to control, it decreased by 1.87 and 1.76fold at 50 and 65 DAS, respectively, with $2.0 \mathrm{mg} \mathrm{Cr}$ (VI) $\mathrm{kg}^{-1}$ soil. In stem, also, it followed a similar trend as that observed in leaves, that is, zinc content decreased from 18.86 to $10.34,43.23$ to 28.64 , and 38.87 to $25.66 \mu \mathrm{g} \mathrm{g}^{-1}$ dry weights at 30,50 , and 65 DAS, respectively. In leaves, stem, and root, $\mathrm{Zn}$ content decreased by $46.5,33.7$, and $43.1 \%$ over the control at $50 \mathrm{DAS}$ with $2.0 \mathrm{mg} \mathrm{Cr}$ (VI) kg ${ }^{-1}$ soil, respectively. It increased significantly with progress of growth and had maximum value at 50 DAS followed by decrease at 65 DAS in leaves, stem, and root (Table 7).

The levels of macronutrient contents like $\mathrm{K}, \mathrm{Fe}$, and $\mathrm{Zn}$ decreased while $\mathrm{Na}$ content increased with increase in $\mathrm{Cr}$ concentration. It is suggested that the uptake and the translocation of mineral nutrients are affected differently by $\mathrm{Cr}$. Cr interferes with entrance of some cations like $\mathrm{K}, \mathrm{Ca}$, $\mathrm{Mg}, \mathrm{Fe}$, and $\mathrm{Zn}$ into roots and affected inorganic feeding of plant due to similar structure with these inorganic elements including $\mathrm{P}$ and $\mathrm{N}$ [40]. It acutely reduced their movement and absorbance. Ali et al. [41] also reported that $\mathrm{Cr}$ stress decreased $\mathrm{K}, \mathrm{Fe}$ and $\mathrm{Zn}$ concentration and accumulation in barley plants. Reduced uptake of these elements may be due to breakdown of membrane function and inhibition of $\mathrm{H}^{+}$ATPase, which hampers nutrient and water uptake [31] and plays an important role in the transport of multiple ions through plasma membrane [42]. It has been reported that inhibition in activity of $\mathrm{H}^{+}$-ATPase membrane pump by $\mathrm{Cr}$ might be due to changes in structure and destruction of membrane by free radicals formation.

3.2. Guar Gum Content. Guar gum is a neutral polysaccharide consisting of beta-D-mannose backbone with side chains of alpha $(1 \rightarrow 6)$ linked galactose residues obtained from endosperm of guar seeds [43]. Its synthesis depends upon availability of mannose and galactose units. The present study showed that $\mathrm{Cr}$ toxicity has negative effect on guar gum in seeds. Gum content in seeds at 65 DAS decreased with increasing Cr levels from 0.0 to $2.0 \mathrm{mg} \mathrm{Cr}$ (VI) $\mathrm{kg}^{-1}$ soil. 
TABLE 6: Effect of $\mathrm{Cr}(\mathrm{VI})$ on iron content ( $\mu \mathrm{g} \mathrm{g}^{-1}$ dry weight) in clusterbean plant parts at different stages of growth.

\begin{tabular}{|c|c|c|c|c|c|c|c|c|c|}
\hline \multirow{3}{*}{$\begin{array}{l}\mathrm{Cr}(\mathrm{VI}) \\
\mathrm{mg} \mathrm{kg}^{-1} \text { soil }\end{array}$} & \multicolumn{9}{|c|}{ Days after sowing (DAS) } \\
\hline & 30 & 50 & 65 & 30 & 50 & 65 & 30 & 50 & 65 \\
\hline & & Leaves & & & Stem & & & Root & \\
\hline 0.0 & 253.45 & 384.28 & 324.45 & 183.54 & 295.72 & 234.70 & 128.42 & 184.84 & 146.22 \\
\hline 0.5 & 147.54 & 235.44 & 115.42 & 117.22 & 166.38 & 145.14 & 104.79 & 139.69 & 113.46 \\
\hline 1.0 & 99.14 & 123.05 & 105.41 & 85.12 & 113.26 & 94.61 & 68.35 & 92.82 & 79.82 \\
\hline \multirow[t]{2}{*}{2.0} & 57.13 & 80.61 & 64.64 & 44.78 & 65.12 & 52.41 & 38.13 & 66.33 & 49.55 \\
\hline & A & B & $\mathrm{A} \times \mathrm{B}$ & $\mathrm{A}$ & B & $\mathrm{A} \times \mathrm{B}$ & A & $\mathrm{B}$ & $\mathrm{A} \times \mathrm{B}$ \\
\hline $\mathrm{SE}(\mathrm{m})$ & 0.04 & 0.05 & 0.09 & 0.01 & 0.02 & 0.03 & 0.03 & 0.04 & 0.07 \\
\hline $\mathrm{CD}$ at $5 \%$ & 0.13 & 0.15 & 0.27 & 0.05 & 0.06 & 0.10 & 0.09 & 0.11 & 0.21 \\
\hline
\end{tabular}

TABLE 7: Effect of Cr (VI) on zinc content ( $\mu \mathrm{g} \mathrm{g}^{-1}$ dry weight) in clusterbean plant parts at different stages of growth.

\begin{tabular}{|c|c|c|c|c|c|c|c|c|c|}
\hline \multirow{3}{*}{$\begin{array}{l}\mathrm{Cr}(\mathrm{VI}) \\
\mathrm{mg} \mathrm{Kg}^{-1} \text { soil }\end{array}$} & \multicolumn{9}{|c|}{ Days after sowing (DAS) } \\
\hline & 30 & 50 & 65 & 30 & 50 & 65 & 30 & 50 & 65 \\
\hline & \multicolumn{3}{|c|}{ Leaves } & \multicolumn{3}{|c|}{ Stem } & \multicolumn{3}{|c|}{ Root } \\
\hline 0.0 & 33.42 & 47.36 & 38.20 & 18.86 & 43.23 & 38.87 & 21.39 & 28.57 & 25.55 \\
\hline 0.5 & 26.14 & 36.73 & 34.93 & 16.24 & 37.16 & 37.36 & 18.64 & 25.30 & 23.92 \\
\hline 1.0 & 19.22 & 32.61 & 30.65 & 13.76 & 36.17 & 26.46 & 16.73 & 21.47 & 18.37 \\
\hline \multirow[t]{2}{*}{2.0} & 16.98 & 25.32 & 21.65 & 10.34 & 28.64 & 25.66 & 12.65 & 16.26 & 12.13 \\
\hline & $\mathrm{A}$ & $\mathrm{B}$ & $\mathrm{A} \times \mathrm{B}$ & $\mathrm{A}$ & $\mathrm{B}$ & $\mathrm{A} \times \mathrm{B}$ & $\mathrm{A}$ & $\mathrm{B}$ & $\mathrm{A} \times \mathrm{B}$ \\
\hline $\mathrm{SE}(\mathrm{m})$ & 0.06 & 0.07 & 0.01 & 0.02 & 0.03 & 0.05 & 0.04 & 0.04 & 0.08 \\
\hline $\mathrm{CD}$ at $5 \%$ & 0.18 & 0.21 & 0.03 & 0.07 & 0.08 & 0.15 & 0.12 & 0.14 & 0.25 \\
\hline
\end{tabular}

Maximum decrease was noticed in seeds of $2.0 \mathrm{mg} \mathrm{Cr}$ (VI) $\mathrm{kg}^{-1}$ soil treated plants. Gum content in seeds at maturity $(90$ DAS) decreased by $10.3,26.5$, and $40.7 \%$ over the control with $0.5,1.0$, and $2.0 \mathrm{mg} \mathrm{Cr}$ (VI) $\mathrm{kg}^{-1}$ soil treated plants (Figure 1).

This decrease in gum content might be partly due to $\mathrm{Cr}$ interfering in nitrogen metabolism [14], chlorophyll content, and uptake of minerals [41]. The reduced availability of sugar molecules (galactose, mannose) thereby resulted in decrease in gum content at higher concentration of $\mathrm{Cr}$. Further, synthesis of galactomannan gum is an energy (ATP) consuming process [44], and thus reduced availability of ATP under Cr toxicity [45] hampers this process and results in decrease in sugar and gum content.

\section{Conclusion}

In conclusion, results demonstrate that all the endpoints applied were severely affected by $\mathrm{Cr}$. The present study revealed that $\mathrm{Cr}$ content, reducing sugar, and sodium contents were increased under the influence while other parameters decreased under similar conditions and growth stages. Decreased photosynthesis and $\mathrm{Cr}$ accumulation in plant parts are considered to be the most effective in altering other biochemical parameters under $\mathrm{Cr}$ toxicity in soil. The decreased content of minerals and guar gum may also be regarded as decreased nutritional as well as economical values of produce. These are very important aspects for ClusterBean based on its applicability as a fodder crop and source of commercially important guar gum. Therefore, studies are

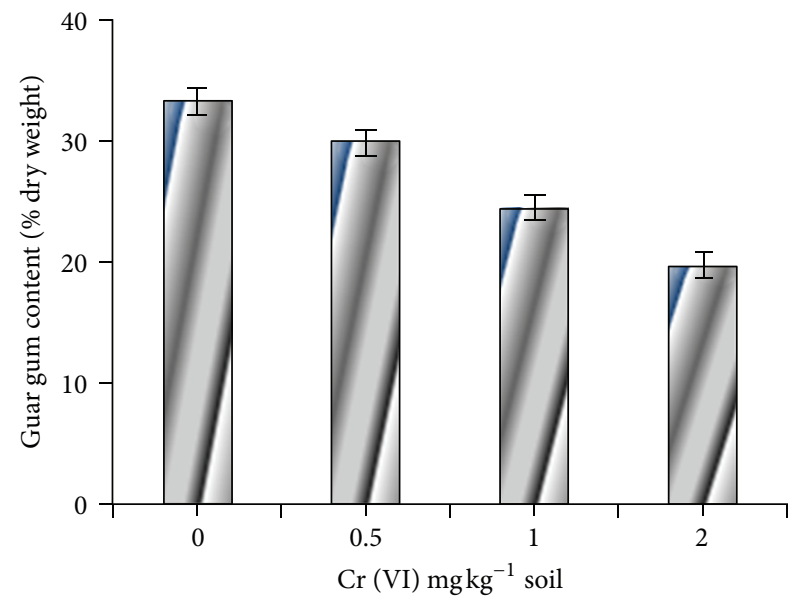

$\square$ Gum content

FIGURE 1: Effect of Cr (VI) on gum content (\% dry weight) in seeds at 90 days after sowing.

required to develop a suitable strategy for amelioration of this $\mathrm{Cr}$ phytotoxicity in order to maintain the content of commercially important compounds and improvement of plant growth and development.

\section{Acknowledgments}

The authors gratefully acknowledge the Director Research and Head, Department of Biochemistry, for providing 
the necessary infrastructural facility. The lead author is grateful to the Indian Council of Agriculture Research (ICAR), for providing financial assistance in the form of ICAR-SRF.

\section{References}

[1] F. Villiers, C. Ducruix, V. Hugouvieux et al., "Investigating the plant response to cadmium exposure by proteomic and metabolomic approaches," Proteomics, vol. 11, no. 9, pp. 16501663, 2011.

[2] N. Rascio and F. Navari-Izzo, "Heavy metal hyperaccumulating plants: how and why do they do it? And what makes them so interesting?" Plant Science, vol. 180, no. 2, pp. 169-181, 2011.

[3] F. T. Davies Jr., J. D. Puryear, R. J. Newton, J. N. Egilla, and J. A. Saraiva Grossi, "Mycorrhizal fungi enhance accumulation and tolerance of chromium in sunflower (Helianthus annuus)," Journal of Plant Physiology, vol. 158, no. 6, pp. 777-786, 2001.

[4] A. K. Shanker, C. Cervantes, H. Loza-Tavera, and S. Avudainayagam, "Chromium toxicity in plants," Environment International, vol. 31, no. 5, pp. 739-753, 2005.

[5] H. Zhang, L.-Y. Hu, P. Li, K.-D. Hu, C.-X. Jiang, and J.-P. Luo, "Hydrogen sulfide alleviated chromium toxicity in wheat," Biologia Plantarum, vol. 54, no. 4, pp. 743-747, 2010.

[6] B. R. James and R. J. Bartlett, "Plant-soil interactions of chromium," Journal of Environmental Quality, vol. 13, no. 1, pp. 67-70, 1984.

[7] A. Baran, Ş. H. Baysal, and A. Sukatar, "Removal of Cr6+ from aqueous solution by some algae," Journal of Environmental Biology, vol. 26, no. 2, pp. 329-333, 2005.

[8] P. Vajpayee, R. D. Tripathi, U. N. Rai, M. B. Ali, and S. N. Singh, "Chromium (VI) accumulation reduces chlorophyll biosynthesis, nitrate reductase activity and protein content in Nymphaea alba L," Chemosphere, vol. 41, no. 7, pp. 1075-1082, 2000.

[9] R. Moral, I. Gomez, J. N. Pedreno, and J. Mataix, "Absorption of $\mathrm{Cr}$ and effects on micronutrient content in tomato plant (Lycopersicum esculentum M.)," Agrochimica, vol. 40, no. 2-3, pp. 132-138, 1996.

[10] A. Kamavisdar, "Heavy metal pollution and their effects on environmental health," Indian Journal of Environmental Protection, vol. 30, no. 4, pp. 335-340, 2010.

[11] P. J. Florijn and M. L. van Beusichem, "Uptake and distribution of cadmium in maize inbred lines," Plant and Soil, vol. 150, no. 1, pp. 25-32, 1993.

[12] D. Kumar and N. Singh, Guar in India, Scientific Publishers, 2002.

[13] P. Chandra and K. Kulshreshtha, "Chromium accumulation and toxicity in aquatic vascular plants," Botanical Review, vol. 70, no. 3, pp. 313-327, 2004.

[14] S. Kumar and U. N. Joshi, "Nitrogen metabolism as affected by hexavalent chromium in sorghum (Sorghum bicolor L.)," Environmental and Experimental Botany, vol. 64, no. 2, pp. 135$144,2008$.

[15] J. Hiscox and G. Israelstam, "A method for the extraction of chlorophyll from leaf tissue without maceration," Canadian Journal of Botany, vol. 57, pp. 1332-1334, 1979.

[16] N. Nelson, "A photometric adaptation of the Somogyi method for the determination of glucose," Journal of Biological Chemistry, vol. 153, pp. 375-380, 1944.

[17] AOAC, Official Methods of Analysis, Association of Official Analytical Chemists, Washington DC, USA, 15th edition, 1990.
[18] B. Das, S. K. Arora, and Y. P. Luthra, "A rapid method for determination of gum in guar (Cyamopsis tetragonoloba (L.) Taub.)," in Proceedings of the 1st Institute for Conflict Analysis and Resolution Workshop (CAZRI '77), pp. 117-123, Jodhpur, India, 1977.

[19] U. N. Joshi, "Advances in chemistry, biochemistry and industrial utilization of guar seed," in Guar, J. V. Singh and B. S. Dahiya, Eds., p. 197, Indian Society of Forage Research, Hisar and Agricultural and Processed Food Products Export Development Authority (APEDA), New Delhi, India229, 2004.

[20] N. Gauba, M. Mahmooduzzafar, T. O. Siddiqi, S. Umar, and M. Iqbal, "Leaf biochemistry of Lycopersicon esculentum Mill. at different stages of plant development as affected by mercury treatment," Journal of Environmental Biology, vol. 28, no. 2, pp. 303-306, 2007.

[21] K. Mishra, K. Gupta, and U. N. Rai, "Bioconcentration and phytotoxicity of chromium in Eichhornia crassipes," Journal of Environmental Biology, vol. 30, no. 4, pp. 521-526, 2009.

[22] A. Ghani, "Effect of chromium toxicity on growth, chlorophyll and some mineral nutrients of Brassica juncea L," Science and Technology, vol. 4, pp. 197-202, 2011.

[23] R. Hamid, J. A. Parray, A. N. Kamili, and Mahmooduzzafar, "Chromium stress in Brassica juncea L. cv. 'Pusa Jai Kissan' under hydroponic culture," African Journal of Biotechnology, vol. 11, pp. 15658-15663, 2012.

[24] H. Diwan, A. Ahmad, and M. Iqbal, "Chromium-induced alterations in photosynthesis and associated attributes in Indian mustard," Journal of Environmental Biology, vol. 33, pp. 239-243, 2012.

[25] S. Choudhury and S. K. Panda, "Induction of oxidative stress and ultrastructural changes in moss Taxithelium nepalense (Schwaegr.) Broth. under lead and arsenic phytotoxicity," Current Science, vol. 87, no. 3, pp. 342-348, 2004.

[26] V. Rai, P. Vajpayee, S. N. Singh, and S. Mehrotra, "Effect of chromium accumulation on photosynthetic pigments, oxidative stress defense system, nitrate reduction, proline level and eugenol content of Ocimum tenuiflorum L," Plant Science, vol. 167, no. 5, pp. 1159-1169, 2004.

[27] K. S. Ganesh, L. Baskaran, S. Rajasekaran, K. Sumathi, A. L. A. Chidambaram, and P. Sundaramoorthy, "Chromium stress induced alterations in biochemical and enzyme metabolism in aquatic and terrestrial plants," Colloids and Surfaces B, vol. 63, no. 2, pp. 159-163, 2008.

[28] R. Solanki and R. Dhankhar, "Biochemical changes and adaptive strategies of plants under heavy metal stress," Biologia, vol. 66, no. 2, pp. 195-204, 2011.

[29] K. K. Tiwari, S. Dwivedi, N. K. Singh, U. N. Rai, and R. D. Tripathi, "Chromium (VI) induced phytotoxicity and oxidative stress in pea (Pisum sativum L.): biochemical changes and translocation of essential nutrients," Journal of Environmental Biology, vol. 30, no. 3, pp. 389-394, 2009.

[30] N. Hamid, N. Bukhari, and F. Jawaid, "Physiological responses of Phaseolus vulgaris to different lead concentrations," Pakistan Journal of Botany, vol. 42, no. 1, pp. 239-246, 2010.

[31] M. Najafian, F. Kafilzadeh, H. N. Azad, and Y. Tahery, “Toxicity of chromium (Cr6+) on growth, ions and some biochemical parameters of Brassica napus L," World Applied Sciences Journal, vol. 16, no. 8, pp. 1104-1109, 2012.

[32] R. S. Dubey and A. K. Singh, "Salinity induces accumulation of soluble sugars and alters the activity of sugar metabolising enzymes in rice plants," Biologia Plantarum, vol. 42, no. 2, pp. 233-239, 1999. 
[33] J. Datta, A. Bandhyopadhyay, A. Banerjee, and N. Mondal, "Phytotoxic effect of chromium on the germination, seedling growth of some wheat (Triticum aestivumL.) cultivars under laboratory condition," Journal of Agricultural Science and Technology, vol. 7, pp. 395-402, 2011.

[34] S. Hayat, G. Khalique, M. Irfan, A. S. Wani, B. N. Tripathi, and A. Ahmad, "Physiological changes induced by chromium stress in plants: an overview," Protoplasma, vol. 249, pp. 599-611, 2012.

[35] Y. Zuo, Y. Liu, F. Zhang, and P. Christie, "A study on the improvement iron nutrition of peanut intercropping with maize on nitrogen fixation at early stages of growth of peanut on a calcareous soil," Soil Science and Plant Nutrition, vol. 50, no. 7, pp. 1071-1078, 2004.

[36] N. Pandey and C. P. Sharma, "Chromium interference in iron nutrition and water relations of cabbage," Environmental and Experimental Botany, vol. 49, no. 3, pp. 195-200, 2003.

[37] S. M. Aguilera, G. Borie, P. Peirano, M. Rodriguez, I. Grez, and H. Zunino, "Chemical characterization of sewage sludges in Chile and their potential utilization as amendment to reclaim soils for forestation purposes," Journal of Plant Nutrition, vol. 30, no. 12, pp. 1993-2003, 2007.

[38] H. Liu, J. Zhang, P. Christie, and F. Zhang, "Influence of iron plaque on uptake and accumulation of Cd by rice (Oryza sativa L.) seedlings grown in soil," Science of the Total Environment, vol. 394, no. 2-3, pp. 361-368, 2008.

[39] H. Marschner, "Adaptation of plants to adverse chemical soil conditions," Mineral Nutrition, vol. 2, pp. 596-680, 1995.

[40] A. Kabata-Pendias and H. Pendias, Trace Elements in Soils and Plants, CRC Press, Boca Raton, Fla, USA, 3rd edition, 2001.

[41] S. Ali, S. Cai, F. Zeng, B. Qiu, and G. Zhang, "Effect of salinity and hexavalent chromium stresses on uptake and accumulation of mineral elements in barley genotypes differing in salt tolerance," Journal of Plant Nutrition, vol. 35, no. 6, pp. 827-839, 2012.

[42] Q. Shi and Z. Zhu, "Effects of exogenous salicylic acid on manganese toxicity, element contents and antioxidative system in cucumber," Environmental and Experimental Botany, vol. 63, no. 1-3, pp. 317-326, 2008.

[43] S. Sarkar, S. Gupta, P. S. Variyar, A. Sharma, and R. S. Singhal, "Irradiation depolymerized guar gum as partial replacement of gum arabic for microencapsulation of mint oil," Carbohydrate Polymers, vol. 90, pp. 1685-1694, 2012.

[44] S. K. Arora, "Legume carbohydrates," in Chemistry and Biochemistry of Legume, S. K. Arora, Ed., pp. 1-59, Oxford and IBH Publishing Corporation, New Delhi, India, 1982.

[45] A. Dua, Effect of Cr (VI) on carbon metabolism of germinating pea seed [Ph.D. thesis], CCS HAU, Hisar, Haryana, India, 1992. 

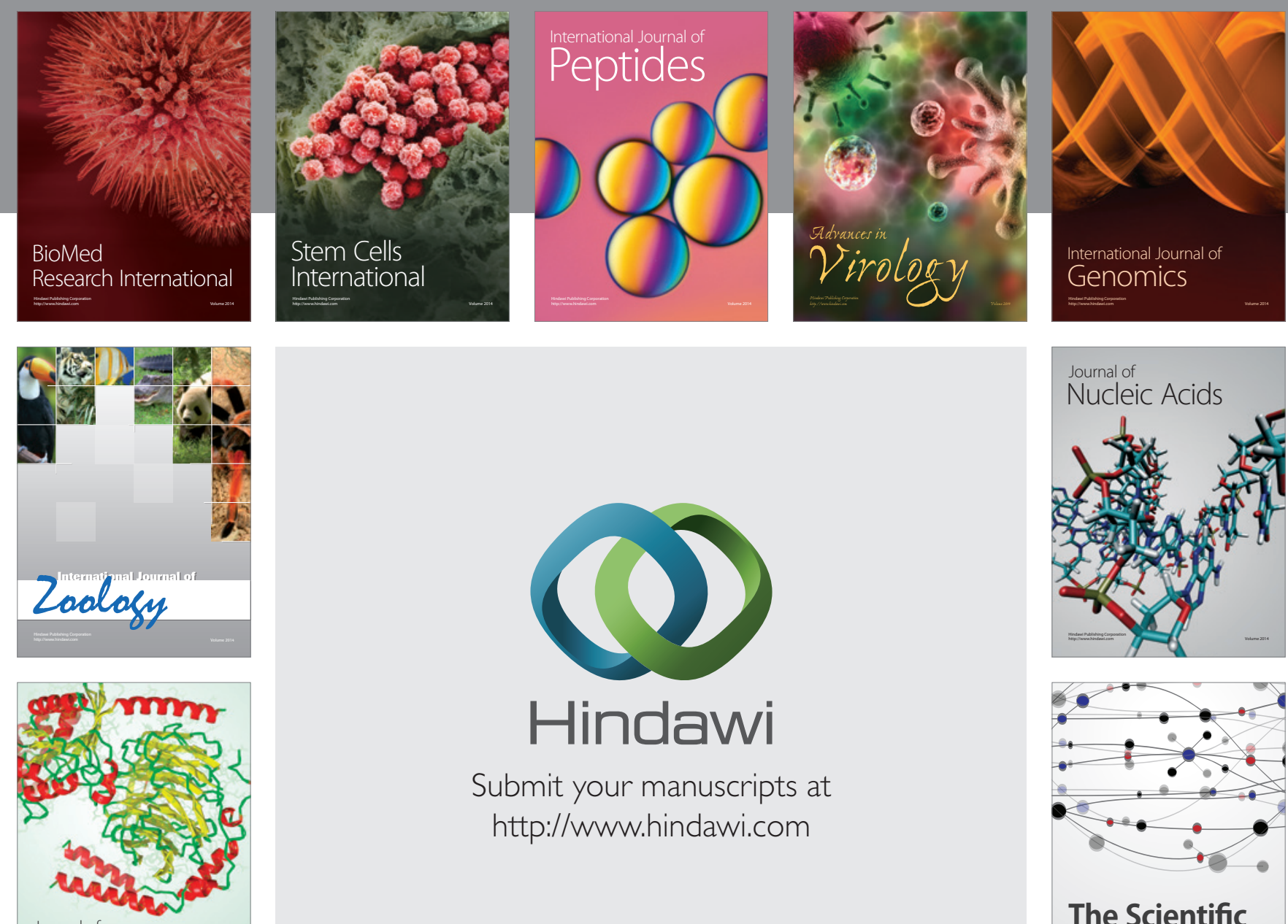

Submit your manuscripts at

http://www.hindawi.com

Journal of
Signal Transduction
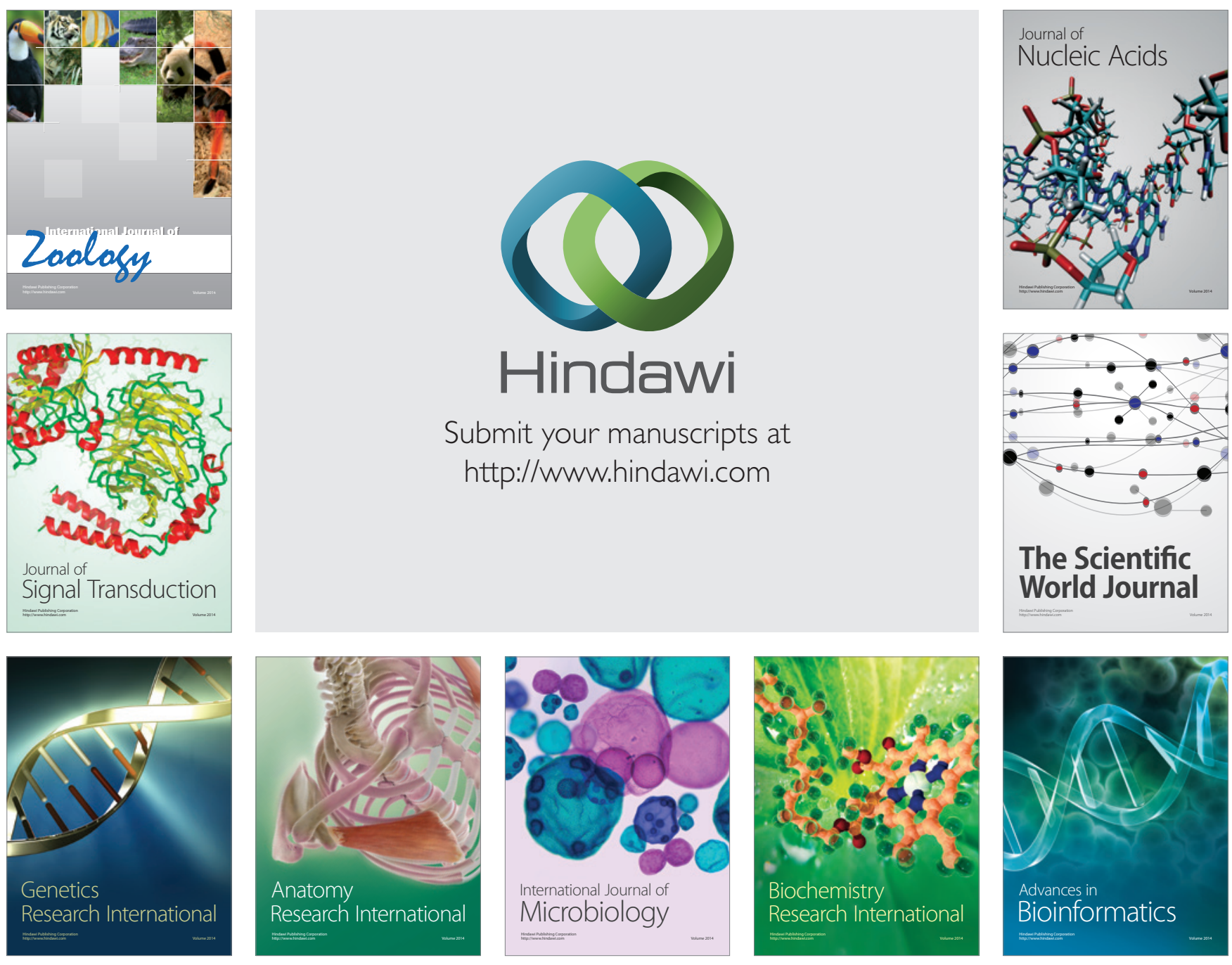

The Scientific World Journal
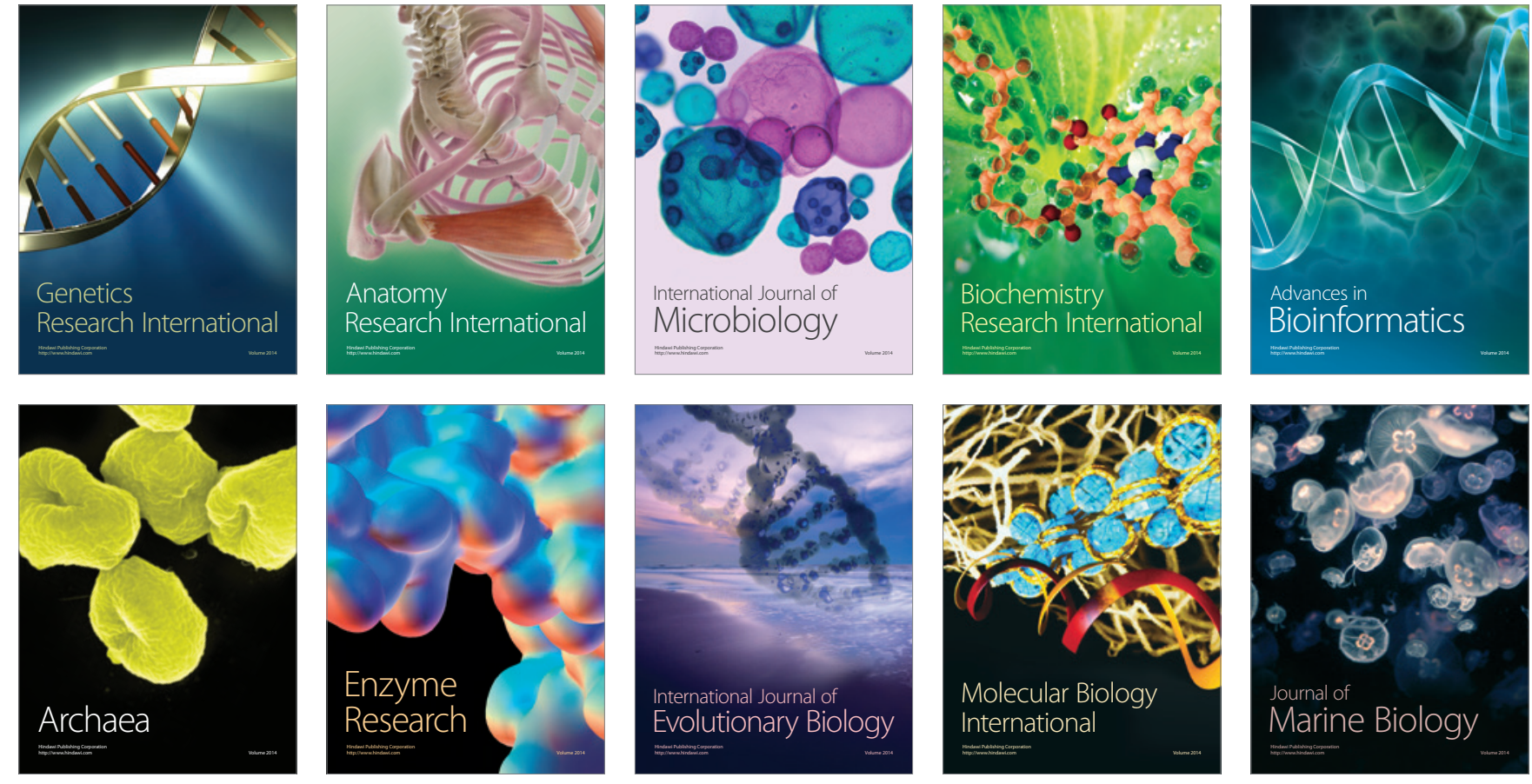